\title{
Playing with the Anthropocene: Board game imaginaries of islands, nature, and empire
}

\author{
Hannah Fair \\ School of Geography and the Environment, University of Oxford, UK \\ hannah.fair@ouce.ox.ac.uk
}

\begin{abstract}
The figure of the island as a metonym for the planet is central to many allegories of the Anthropocene. These allegories build upon pre-existing discourses of islands as remote, vulnerable, and timeless, and often portray contemporary island nations as helpless, doomed, and disposable. This article focuses on one allegorical terrain that has received limited discursive and cultural analysis: analogue board games. Board game representations of islands are relevant to island studies both due to the popularity of island themes and because of the resonances between common island imaginaries and the form of board game play itself. Looking at three explicitly island-themed board games (Taluva, Vanuatu, and Spirit Island), I explore the extent to which these games reiterate or contest discourses of islands as sites of ahistorical insularity and alterity. I investigate the presence and absence of islanders in these fictional landscapes, the relationship between these ludic cartographies and imaginaries of ecological collapse and environmental intervention, and the articulations of nature, humanity, and empire that are literally at play. Particularly in the case of Spirit Island, these board game representations reflect the potential for the figure of the island to be reconfigured in order to imagine the Anthropocene otherwise.
\end{abstract}

Keywords: Anthropocene, board games, climate change, decolonising, islands, Oceania

https://doi.org/10.24043/isj.165 • Received June 2020, Early access April 2021

(C) Island Studies Journal, 2022

\section{Introduction}

The concept of the Anthropocene is gaining increasing traction across the natural and social sciences, and in the broader public sphere (Chua \& Fair, 2019). The recognition that we now live in a geological epoch in which humans have become a defining and destructive force shaping planetary systems (Crutzen, 2002) has raised questions not only of when the Anthropocene began (Lewis \& Maslin, 2015) and what it should be called (Haraway, 2016), but also of how it should be represented and narrated in order to cultivate responsibility in this age of loss and extinctions (Tsing et al., 2017).

Elizabeth DeLoughrey (2019) proposes that in response to these current planetary crises, we are witnessing a revitalisation of allegory. In particular, she interrogates the figure of the island-as-the-world as central to many allegories of the Anthropocene. Analysing examples of early 2000s Tuvalu-focused climate change documentaries, she identifies a form of salvage 
environmentalism, in which the ecologically threatened island acts as a metonym for planetary future, while islanders (themselves figured as an endangered species) are made to stand in for pre-modern innocence and lost nature (DeLoughrey, 2019). These elegiac representations deny contemporary and historic relationships between the Pacific Island region, empire, and capitalism, and designate the islands as outside of continental modernity, presenting them as anachronistic and allochronic, or as operating in another time. These ahistorical representations occlude the causal links between anthropogenic climate change, the actions of industrial nations, and the impacts experienced in low-lying island states, thereby negating rather than fostering responsibility for our Anthropocenic condition.

This article attempts to further interrogate these 'Anthropocene Islands', allegorical representations of catastrophic relationships between humans and nature (largely focused on anthropogenic climate change) in which the island acts as an allegory for the world, but which is often divorced from the material, social, and ecological realities of island life. While such representations have been closely examined in documentaries (DeLoughrey, 2019; Chambers \& Chambers, 2007), journalistic accounts (Farbotko, 2005), and popular scientific publications (Kempf, 2015), I turn to an allegorical terrain that has received limited discursive and cultural analysis: analogue board games. I contend that board game representations of islands are relevant to island studies both due to the popularity of island themes within analogue board games and because of the resonances between common island imaginaries and the form of board game play itself. Looking at three recent, explicitly island-themed board games (Taluva, Vanuatu, and Spirit Island), I explore the extent to which these games reiterate or contest discourses of islands as sites of ahistorical insularity and alterity (Kempf, 2015). I investigate the presence and absence of islanders on these fictional landscapes, the relationship between these ludic cartographies and imaginaries of ecological collapse and environmental intervention, and the articulations of nature, humanity, and empire that are literally at play. Particularly in the case of Spirit Island, these board game representations reflect the potential for the figure of the island to be reconfigured in order to imagine the Anthropocene otherwise.

\section{Board games as island studies terrain}

While non-digital games, including analogue board games, "nevertheless exemplify contemporary cultural forms" (Torner et al., 2016, p. 2), they are situated at the margins of game studies, and of cultural analysis more broadly. This in spite of their escalating popularity, with the board game market predicted to grow by US $\$ 5.81$ billion from 2020-2024 (Technavio, 2020), a trend that in the short term appears to be bolstered by the COVID-19 pandemic and the consequential emphasis on indoor activities, with board game sales in the UK rising by $240 \%$ in the first week of the nation's first lockdown (Butler, 2020). Notably, sales of the board game Pandemic and its expansions and variations have skyrocketed since March 2020 (Schelle, 2020), suggesting the value analogue games might provide in understanding and engaging with serious issues such as disease spread (Beattie, 2020), although the release of the much-anticipated Pandemic Legacy: Season 0 was initially postponed due to its potentially disrespectful allegorical intensity in the current moment (Meehan, 2020).

Not only do board games bear a cultural relevance that is generally underexamined, but I contend that the board game form has a distinct resonance in relation to representations of islands. This is due both to the frequent adoption of island themes in board games (a number 
of examples of which will be discussed at length later in this piece) and to a convergence between common island imaginaries and conceptualisations of the board as a bounded space of play, as envisioned through the metaphor of 'the magic circle'.

Firstly, by common island imaginaries, I reference the "colonial constructions, Eurocentric imagery, and continental projections that have long characterised Western discourses on islands" (Kempf, 2015, p. 202). While these imaginaries may have their origins in imperial pasts, as Katerina Teaiwa (2014, p. 81) notes, "discourses of boundedness, smallness, peripherality, instability and the helplessness of small island states and their peoples still persist." This is particularly apparent in current media representations of Pacific Islands, particularly in relation to climate change (Farbotko, 2005) which tend to emphasise islanders as victims and prospective "climate refugees" facing the inevitable total loss of their homelands. These imaginaries are the foundations of the allegories earlier identified by DeLoughrey (2019). While the current rethinking of the island as a figure of the Anthropocene has been expansively geographically applied (Chandler \& Pugh, 2021), here I specifically focus on the relationship between these island imaginaries and the Pacific Island region, due to the privileged place the latter holds in climate change discourses. As Mike Hulme (2016, p. 101) observes, "part of the familiar visual vocabulary of changing climates and rising sea-level is the Pacific island atoll and the stranded helpless island victim forced to migrate and in need of 'saving' by an enlightened world."

Kempf (2015, p. 203) pinpoints three underlying principles of external, continental representations of islands: "insularity, concretion, and alterity." The former establishes an understanding of islands as remote and bounded, meanwhile concretion supposes that islands, due to their small size and boundedness, are "intrinsically transparent and graspable" (Kempf, 2015 , p. 204). This aligns with the mythology of the island as laboratory (Farbotko, 2010), a discrete and closed site of experimentation that excises some of the uncertainties of knowledge production. The island laboratory framing easily segues into the island-as-the-world allegory, as, for instance, the fate of the planet in the face of global warming is miniaturised in relation to low-lying island countries such as Tuvalu. As Farbotko (2010) highlights, this both makes global processes comprehensible and manageable, and brings them forward in time, as in many articulations Tuvalu is presented as already lost to rising seas.

Finally, alterity emphasises both the otherness and inferiority of island and islanders in comparison with continental powers, and encompasses tropes of primitiveness, timelessness, or staticity, presenting Pacific Island nations as outside of or in opposition to modernity. These discursive acts of othering also justify the usage of the island as a laboratory and the potential suffering and losses that occur through doing so. Farbotko (2010) captures this presumed expendability through the notion of "wishful sinking," as she argues that in some environmentalist discourses the devastation of nations such as Tuvalu becomes an acceptable price to pay for the irrefutable evidence of anthropogenic climate change. Like the proverbial canary in the coal mine, Tuvalu is produced as valuable only through the knowledge and certainty gained through its loss.

Many of these properties associated with the imaginative geographies of islands are also commonly attributed to the form of play engaged in through board games. Unlike the expansive, explorative digital cartographies offered by video games, many board games function through an isolated boundedness (the physical constraints of the board, the clear and fixed demarcation of players), operating with certainty and concretion (through the explicit 
articulation of knowable rules). Moreover, board games, while often thematically situated in a specific historic period, enact a refusal of linear time, due to the potential for reversibility of all actions through future replaying. Therefore, they are deprived of the sense of continuity and narrative present in many video games. Board games are won or lost, but it is rare that they are completed. Akin to the island imaginaries discussed above, they can therefore also be understood as allochronic and ahistoric. They also embody the mode of the idealised, closed experimental setting, where knowledge and skill can be accumulated through trial and error. Admittedly, this aspect may have been challenged by the rise of legacy games, which are premised on the enduring consequences of actions for future games and "double irreversibility" (Mosca, 2017, para. 14), both in terms of the potential for the permanent death and destruction of characters and physical pieces within the game, as well as the death of the role of player, as legacy games, once completed, cannot be replayed. That said, legacy games, while popular, reflect a currently marginal tendency in contemporary board game production.

These dimensions of alterity, physical boundedness, and existence outside of linear time reflect aspects of 'the magic circle', a much debated metaphor within games studies. The metaphor seemingly originates with Huizinga (1938, p. 10, as cited in Stenros, 2014, p. 148), who describes "forbidden spots, isolated, hedged round, hallowed, within which special rules obtain. All are temporary worlds within ordinary world, dedicated to the performance of an act apart." This idea has been developed by later scholars to recognise the psychological, social, and cultural boundaries that exceptionalise and delimit a separate and enclosed space of play in relation to the wider world (Stenros, 2014). A range of alternative metaphors to that of the circle have been supplied in order to analyse this phenomenon central to games, including "world, frame, bubble, screen, membrane, reality, zone, environment and net" (Stenros, 2014, p. 155). But I contend that, figuratively speaking, while no man is an island, perhaps every board game is? Or, at least, the synergies between the discursive representation of islands as enclosed and contained experimental sites and the conscious constructions of board games as such may speak to some of the popularity of island themes within contemporary board games.

Within the category of strategy board games, perhaps one of the most iconic - and commercially successful - games is rooted in islandness. Catan (originally published in 1995 as Die Siedler von Catan or The Settlers of Catan) has sold over eighteen million copies globally (Raphael, 2014), been translated into over thirty languages (Wired, 2009), and has been described as "the great board game of this era" (Eskin, 2010, para. 3). In the base game of Catan, the board is a single island made out of randomly distributed hexes, each representing different terrains able to yield different types of resources. The island, with its many resources (wood, ore, wool, grain, and brick), is ripe for exploitation, and the mainstay of the game is the settlement of the island by the players through the building of roads and cities. The only ambivalent potential figure of island Indigeneity is that of the robber, who begins the game positioned in the desert, the one barren segment of terrain on the board. The robber is thus figured as inherently unproductive, surviving only through theft from other players when a seven is thrown or employed through mercenary service as a knight in one of the few combative elements of the game. Whether or not the figure of the robber stands in for a displaced and derided pre-colonial Indigenous presence is unclear. Yet clearly Catan largely imagines an island without islanders, in an unmitigated colonial fantasy, purified of the violence of invasion.

Robinson (2016) contends that this failure to address the realities of colonial violence is a consequence of the Eurogame form itself. As distinct from American style war games, 
Eurogames largely avoid conflict-based mechanisms and the destruction or elimination of other players, with victory instead emerging from the player's own self betterment in terms of economic and infrastructural development. Eurogames emerged in Germany with an explicitly non-militaristic ethos, and are designed to enable balanced and fair competition throughout the entire game. Yet this is at odds with the common adoption of colonialization as a Eurogame theme, as is also found in Vasco da Gama and Archipelago, for instance. In order to accommodate this within the Eurogame form, violence is abstracted, portraying European expansionism in purely economic terms and thereby distorting history (Robinson, 2016).

There have been critical reworkings of Catan's colonial setting. Loring-Albright (2017) reads Catan as an analogue for New World exploration and a perpetuation of frontier mythology of an empty and Edenic American West that renders Native Americans invisible. Consequently, he produced the game modification The First Nations of Catan (Loring-Albright, 2017) which endeavours to highlight Indigenous presence and agency through the creation of a First Nations character who has a distinct and asymmetrical mode of play. The modification works to reflect the violence of settler colonialism through introducing new combat mechanisms that, aligned with Robinson's (2016) analysis, disrupt the tenets of Eurogaming. Additionally, the recent rebranding of the game from The Settlers of Catan to simply Catan could be interpreted as a degree of discomfort with the legacy of colonialism that Catan fails to meaningfully engage with. Meanwhile, in response to the COVID-19 pandemic, the designers of Catan released a free miniature "\#WeStayHome" scenario (https://www.catan.com/game/catan-westayhome) with two new 'Home' hexes to encourage lockdown adherence. In this scenario, the robber, in a Robin Hood-esque move, rather than stealing from players, rewards those who "stay near home" with additional resources. Irrespective of the impacts of the kindly robber game mechanics, if we continue to read the robber through a decolonial lens of disenfranchised Indigeneity, such a rehabilitation of character is still far from the reparations owed. This question of the relationship to empire, history, and violence continues with more recently produced games, as will become apparent in the later discussions of Spirit Island, which can be seen as explicit anti-colonial rejoinder to Catan as a genre-defining strategy game.

While I contend that many board games are islands, whether literally in their thematic dimensions or figuratively in their contained, bounded, and experimental forms, not all board games are Anthropocene Islands. Catan remains undeniably Holocenic. Not only do the graphics convey a generic medievalism (indeed, the designer, Klaus Teuber, cites Viking inspiration for the game's setting [Raphel, 2014]), but the relationships between ecological systems and human exploitation and extraction are entirely unproblematised. However, a number of descendant games within the Eurogame tradition of Catan both thematically figure island worlds and explore the tensions and imbrications of the human and the natural at the heart of the Anthropocene epoch. To elucidate this, for the remainder of this article I will focus on three games - Taluva, Vanuatu, and Spirit Island - all of which centre islands (and, to some extent, islanders). The critiques that follow centre upon the thematic and metaphorical portent of the games, not the experience of play per se, and should not be read as evaluations of their ludic quality. Such a list of island-themed games is not exhaustive, but these examples are perhaps indicative of current trends within board games narratives, and all three games in their own ways are good to think with. 


\section{Three Anthropocene islands}

\section{Taluva: Dreams of mastery and invisible islanders}

I begin with Taluva, a tile placement game released in 2006. During the game, an island is progressively created through players competitively laying landscape tiles and then building huts, temples, and towers. Victory is achieved through the combination of buildings placed and, in line with the Eurogame ethos, the game is largely non-combative, with the exception of the 'volcanic eruptions' that occur when volcanic tiles are placed over each other, leading to players' huts being engulfed in lava and removed from the board.

Taluva embodies the shallow use of thematic settings identified by Faidutti (2017, p. 25), who argues that board game designers often just draw upon "topoi, sets of standard references," as the game appears to present a homogenous pastiche of Pacific Islands. While the designer's inspirations for the name cannot be conclusively determined, it can be noted that "taluva" appears as a word in both Estonian and Hindi (meaning "tolerant" and "sole of the foot", respectively) but does not seem to be drawn from any Pacific Island language. Instead, it appears to function as a near anagram of the name "Tuvalu". If this anagrammatical allusion is indeed intended, then the swapping of letters, and the swapping of a low-lying atoll nation for an incongruously mountainous volcanic terrain, parallels the homogeneity and fungibility with which the Pacific Island region is regularly figured in contemporary climate change discourse. Islanders do not themselves appear in the game. As is a common mechanic, they are represented simply by their settlements - settlements that can be placed or destroyed, but do not have other moves that can shape the course of action. By contrast, the players are godlike, bringing forth geomorphic creation and wreaking volcanic destruction upon the land.

Reading this game mechanic through the lens of the Anthropocene suggests two alternate interpretations. Firstly, that we are firmly in the Holocene: humans are not deeply imbricated in all planetary processes; instead, Nature, as distinct, uncontrollable, and aweinspiring, has the might to ruin our small human worlds. Such an interpretation would be fitting if the volcanic eruptions were controlled by the board (as in many co-operative board games, for example Pandemic, Bloc by Bloc, or the soon to be discussed Spirit Island, players play against the randomised actions of the board itself). However, here it is players that wield volcanic powers. Consequently, this game lends itself to the "dream of mastery" (Wapner, 2010, as cited in Lorimer, 2015, p. 2) reading of the Anthropocene, in which the new epoch is understood as an opportunity for further human advancement through deliberate intervention into planetary processes. In this game, the hubristic fantasy that humans are as gods is borne out. The concept of the Anthropocene has been critiqued for enabling such fantasies, as through its very nomenclature it centres and thereby aggrandises the power and agency of the Human (Crist, 2016), perpetuating a form of species exceptionalism and conflating human influence with human control rather than encouraging the humility needed in an age of extinctions (Haraway, 2016; Nixon, 2017).

Yet, Taluva is also far from the vision of techno-optimism that frequently accompanies such a narrative. It can also be read as an allegory of climate catastrophe. Firstly, the image of the volcano is apt, due to the complex relationship between climate change and volcanism. Not only do volcanic eruptions have impacts both on global temperatures and greenhouse gas emissions, but there is emerging evidence that the frequency and intensity of eruptions is affected by rapid glacial melt (McConnell et al., 2017; Swindles et al., 2018). If we seep into 
the allegory of island-as-the-world, then the game demonstrates that the malign impacts of humans upon natural processes are leading us to current and future widespread devastation, even as we continue to build our towers and temples, greater and greater feats of human ingenuity. Moreover, if we reign in our metaphor back to the Pacific, then the inequities of the Anthropocene also shine through. The huts sacrificed to lava flows to enable temples and towers to ascend to the skies act as symbols for the Pacific Island communities that are deeply imperilled by the continued excessive emissions of industrialised nations. Such a reading leans further into the decolonial and intersectional critiques of mainstream Anthropocene discourse, which recognise that Humanity is not a homogenous and universal figure that is evenly responsible for our current predicament. Speaking of a singular Anthropos "legitimates a biopolitics that masks differential human responsibilities for and exposures to planetary change" (Lorimer, 2015, p. 3). Instead, the Anthropocene has been interpreted as deeply racialised and racialising. Drawing together histories of slavery, extraction, and imperialism with contemporary experiences of environmental racism, Kathryn Yusoff (2018) argues that it is largely black and brown bodies who have born the weight of Anthropocene suffering. Meanwhile, North American Indigenous scholars Zoe Todd (2016; Davis \& Todd, 2017) and Kyle Powys Whyte (2018) critique the apocalypticism of contemporary Anthropocene narratives, not on the grounds of its perpetual postponement (Swyngedouw, 2010) but because they argue that the Anthropocene is a continuation of environmental destruction, displacement, and colonial violence: for Native people in the Americas, such world endings already occurred long ago. This speaks to broader critiques of the Anthropocene as a point of awakening and rupture and the concomitant failure to recognise the continuities of historical, ecological, and political processes and struggles between our Holocenic past and now (Bonneuil \& Fressoz, 2016).

Yet, none of these readings - Holocenic denial of our current condition, visions of a godlike Anthropos, or islanders as disposable victims - offer allegories for the Anthropocene that embody islander agency in the face of catastrophic climate change. The latter interpretation showcases power and violence that are inequitably distributed at great human and environmental cost, but it does not take us beyond the figure of the islander as tragic anonymous victim. These representations not only fail to capture the strength and power of contemporary Pacific Islander resistance to climate catastrophe (Fair, 2020; Steiner, 2015) but present a framework that renders such modes of resistance unimaginable.

\section{Vanuatu: Inhabiting islandness meets inevitable inundation}

By contrast, I turn to the board game Vanuatu, which was originally published in 2011 and was re-released as a second edition in 2016. In contrast with Taluva, this game is strongly geographically rooted, and premised upon play not as a superior godlike force, but as a $\mathrm{Ni}$ Vanuatu islander engaged in the everyday work of contemporary economic survival. This game renders islanders visible both through pictorial depictions of different occupations (e.g., fisherman, priest, tour guide) and through the process of playing as them, as taking turns to occupy these different economic roles is the game's main mechanism. That said, only certain islanders are rendered visible, with all the occupations illustrated with images of men in the first edition and gendered nouns used in the English and French language instructions. This is ameliorated by the work of the illustrator of the second edition who instead presents women in the roles of governor, vendor, and guide. 
Far from Taluva's vague anagrammatic affiliation to the Pacific, Vanuatu is explicitly anchored in its eponymous national setting. The game presumes a degree of pre-existing knowledge about the island state, or at least a familiarity with commodities such as kava and copra, represented by small brown cubes that players attempt to export throughout the game. The board also successfully conveys the nation's archipelagic nature (also a feature of the game Kahuna): rather than rendered as one mass of land, the islands of Éfaté, Ambrym, and Espiritu Santo are gradually added to the board, separated by navigable ocean tiles. Central also to the game's islandness, the sea is not read as boundary or void, but is as much a terrain of play as the land tiles are.Vanuatu as a nation is here constituted both by land and sea, resonate of Hau'ofa's (1994) interconnected "sea of islands." The trade mechanism in the game (which also has precedents in Catan which features ports where goods can be sold) also mitigates against visions of Vanuatu as isolated and fragmented "islands in a far sea" (Hau'ofa, 1994, p. 7). Not only are beef, kava, and copra exported to international markets, but a mainstay of the game's economy is the steady flow of tourists - explicitly depicted as white in both game editions - who require guiding, purchase handicrafts, and appreciate sand art. Such details situate Vanuatu as economically interconnected within a global system, thereby rejecting the tropes of insularity (Kempf, 2015) and the allegory of the island as remote and contained laboratory (Farbotko, 2010). These aspects also historically frame the game. Vanuatu (and, indeed,Vanuatu) is not timeless, but explicitly postcolonial: from the name alone, it is apparent that the game cannot be set pre-1980 (the year of the New Hebrides' independence and transformation into a sovereign state). Consequently, while being a game rooted in islandness, it transcends the tropes of backwardness and of the island as excised from modernity (Kempf, 2015). Finally, the game seeks to tentatively contest the capitalist value system, as naturalised through games such as Catan. As is a common mechanic in many games, it operates a dual currency of financial value (here in vatus, the currency of Vanuatu) and victory points (here rendered as 'prosperity' points). Various actions, such as discovering treasure, completing sand drawings, and building huts, generate prosperity points, and a certain accumulation of vatus can also be converted into prosperity. This mode of translation between game currencies is relatively routine and unremarkable, however the game designers attempt to situate it within a Ni-Vanuatu ethical framework, claiming that "In Vanuatu, you see, wealth is not measured by how much one earns, but by how much one gives away" (Epron, 2016, p. 2). This invocation of communalist ethics, kin obligation, and Melanesian traditions of gifting therefore importune the player not just to act as an islander, but to situate themselves within an (albeit crudely configured) Ni-Vanuatu world view.

While Vanuatu speaks to the capacity of board games to portray a geographically and historically situated islandness, with game play not just acknowledging but contingent upon the exercise of islander agency and the rendering visible of diverse modes of island life, it seems to have little bearing upon fundamental questions of the Anthropocene. Yet that is far from the case with the game's sole expansion, Vanuatu: Rising Waters, which introduces attempts at climate change adaptation as an additional game mechanic. Here, however, the geographic specificity of the game becomes unmoored. Compared with the previous engagement with the particularities of Ni-Vanuatu life, with the expansion the designers instead draw upon common imaginaries of Pacific Islands as "sinking nations" (Teaiwa, 2014, p. 69) in the context of climate change. As the rulebook explains, "Global warming threatens Vanuatu. Many islands are in danger of disappearing under the ocean due to rising waters" (Epron, 2016, p. 10). Rising 
Waters embodies the disempowering 'inevitable inundation' discourse that has been heavily critiqued (Fair, 2019; Farbotko, 2010), presenting Vanuatu as a land that will inescapably disappear beneath the waves due to sea level rise. In a reversal of Taluva, where an atoll is rendered volcanic, here the volcanic is refigured as atoll, as Vanuatu is envisioned as perilously low-lying and prone to total submersion, even whilst the imagery of volcanic formations sits prominently on the island tiles.

Rising Waters replicates a narrative of climate urgency that focuses solely on sea level rise, eclipsing the more pressing yet less cinematically sensational concerns that many island nations face (Farbotko, 2005), such as increases in the strength of cyclones or changes in seasonality that impact food security. Thus, through its introduction of a climate change narrative, the game homogenises Vanuatu as part of a generically climate vulnerable and interchangeable Pacific Island region. Moreover, the remedy it presents to such a situation is also misleading. In Rising Waters, the only recourse against total submersion is the building of dikes. Constantly, the game frames climate change responses entirely in terms of local adaptation, divorced from the systemic global factors that have led to these rising seas. This tallies with Barnett and Campbell's (2010, p. 166) assessment of the trope of island vulnerability, as they describe it as "an internal syndrome [which] places the blame with the islands and their peoples. In this way attention is averted from the drivers that create the global warming that the communities have to cope with." This exclusive focus on adaptation coupled with a vision of inevitable submersion works to create a self-fulfilling prophecy, legitimising the failures of climate change mitigation by carbon-intensive countries (McNamara \& Gibson, 2009). With that said, recognising both the damage that islanders themselves have caused to their homelands as well as the impacts of external actors can be critical to foregrounding islander agency, as it prevents action from simply being the prerogative of larger nations. As Hereniko (2014, p. 234) argues, "the sooner we realise that we are also contributors to our own demise, the sooner we will empower ourselves to be part of the solution and not part of the problem." Indeed, narratives of islander responsibility for climate change, framed both in terms of carbon sin and personal preparedness, can form part of empowering political imaginaries (Fair, 2018).

Finally, the solution proposed in Rising Waters (dike building) has been criticised for being potentially maladaptive, exacerbating rather than reducing community vulnerability, as sea walls can disrupt natural erosion processes, negatively impacting livelihoods and having only limited success in reducing exposure to coastal pressures (Piggott-McKellar et al., 2020). Having begun as a game that centred diversified and situated modes of islander agency, through the introduction of a climate change dimension Rising Waters begins to mirror the simplistic narrative of islander victimhood in the face of nature seen in Taluva. Consequently, this game is still limited in its articulation of islander power and agency within an explicitly Anthropocenic island setting.

\section{Spirit Island: Indigenous alliance confronts colonial violence}

In contrast to Catan, Spirit Island is not employed as a tabula rasa, a conveniently empty experimental setting, but as the pre-existing home of fictitious Indigenous people, the Dahan. Players play co-operatively against the game, which sends waves of European settlers to explore, build settlements, and then ravage the island, bringing blight to the land and killing any Dahans in their proximity. The players inhabit the roles of different spirits who, through spreading across the island through the creation of sacred sites, draw upon different powers to 
relocate, kill, or induce fear in the settlers. The settlers are unable to directly attack the spirits, perhaps because they are unaware of their presence, or simply don't believe in them. Consequently, Spirit Island embodies not just a struggle over land, but vying epistemologies and incommensurable ontologies. This speaks to the generative role of islands in Anthropocene thinking, particularly through suggesting alternative ontological frameworks (Chandler \& Pugh, 2021), as Spirit Island dramatises the conflict between modernist attempts to control and purify Nature (as represented by the settlers) and relational entanglements (of people, spirits, and land) that resist such modes of commandment.

In contrast to Taluva, where moves can incidentally destroy invisible and disposable islanders, or Vanuatu, where play is via individual islander figures, Spirit Island encourages play in alliance with the Dahan, who retaliate against settler ravaging but (in most scenarios) do not attack first.Victory is very hard to achieve without working with the Dahan, and for some spirits their strength is intimately bound up with that of the Dahan, as the death of the latter occasions a loss of presence for the former. Yet, unlike a classic worker placement game, players are more constrained in their ability to move the Dahan across the board. The mechanism of playing in alliance with the Dahan rather than simply controlling or deploying them appears to function as a means of conveying Indigenous agency without presuming the ability to adopt an Indigenous positionality. This appears to strike a balance between, on the one hand, attempting to address the underrepresentation of people of colour in board games (as discussed later in relation to Pobuda's [2018] research) and to subvert the colonial imaginaries that haunt many islands (both literal and ludic), while not, on the other hand, encouraging a play-acting of Indigeneity. This suggests an attempt to acknowledge Indigenous epistemologies without appropriating such knowledges (Todd, 2016), but also raises questions about the limits of Huizinga's magic circle, and what temporary ludic worlds can be enacted without perpetuating acts of epistemic violence.

The setting of Spirit Island is intentionally historically and geographically ambiguous. The designer, Eric Reuss (2015a), in his own words, deliberately chose to portray "a conflict that never was, but which could stand in for struggles against different colonial powers throughout history." Consequently, rather than Spirit Island perpetuating the trope of islands as timeless and excised from continental modernity, the malleability of the setting allows the game to be imagined in relation to multiple, specific historic events. Players can engage with named adversaries - the empires of England, Sweden, and Brandenburg-Prussia — but antagonism is not limited to these particular imperial forces. The geographical and historical openness of the setting was designed to enable players to channel their own preferred anticolonial struggle, "so that if someone really wants to feel like they're driving the Invaders out of a (real) land they have some cultural attachment to, they can" (Reuss, 2015b). Consequently, rather than the contemporary synchronic time of Vanuatu, or the eternal premodern allochronic time of Taluva, Spirit Island operates polychronically, speaking to multiple points of time at once. When placed in the context of existing board game tropes, Spirit Island can be recognised as a deliberate political intervention, recognising histories of colonial violence and incorporating them within a Eurogame format. Such an explicitly decolonial reading seems apposite for a game advertising itself as a 'settler-destruction game'.

Yet, a few details jar with this reading. Firstly, the Dahan largely only entering combat in retaliation to colonial incursions portrays them as not proactive but reactive, with the momentum of the game still driven by the European settlers and the players. The role of blight 
in the game set up also raises questions about simplistic representations of Indigeneity. As well as blight being added to the board due to the settlers' actions, the game opens with pre-existing blight on the land. However, the rulebook explains that "A certain amount of blight is normal in nature - such as damage from a forest fire - but too much will overwhelm the island" (Reuss, 2016, p. 15), designating the pre-colonial blight as an emergent ecosystem property rather than the consequence of human actions, thereby running the risk of romanticising Indigenous co-existence with nature.

Another disquieting feature is that the Dahan are represented by their dwellings (akin to Taluva), while the European settlers are figured as individual white humans, as well as in the forms of cities and towns. One explanation for this discrepancy could be the game's deliberate ambiguity of scale, as "a single Dahan piece might represent one village, a few associated villages, or an entire clan" (Reuss, 2015b), thereby potentially facilitating the imagining of Spirit Island as a continental land mass, parallel to Loring-Albright's (2017) reading of Catan as an allegory for the European exploration of the Americas. Yet, this refusal to materially manifest Indigenous people themselves as embodied, while doing so for their white adversaries, reflects a wider trend in under-representation of people of colour in board game design, both behind the scenes and on the boards themselves. As Pobuda (2018) has uncovered, board game design and illustration are dominated by white men, who make up $93.5 \%$ of the designers responsible for the 200 most popular games on BoardGameGeek (a major board games ranking and discussion website). All four games discussed at length in this article are by white male designers, suggesting limitations to the extent to which the games enable the enactment of embodied Indigenous islander agency. Pobuda also found that $45.7 \%$ of board game cover art representations were of white men, compared with those of white women $(14.7 \%)$, men of colour $(7 \%)$, or women of colour (4.7\%). Board games designs are twice as likely to include images of aliens or animals than they are people of colour, suggesting significant issues of diversity and inclusion within the board game industry. However, there is the potential for board games to showcase a greater diversity of perspectives (Torner et al., 2016), as can be seen in examples of collaborative Indigenous game development, with games such as The Gift of Food that are designed to pass on cultural teachings within Native communities (LaPensée, 2016).

While recognising these limitations, Spirit Island still offers a significant decolonial intervention. If one reckons with settler-colonialism as an ongoing apocalypse (Whyte, 2018), then Spirit Island acts not just a historical homage, but a recognition of continuing systemic racist displacement and colonial violence. Through this lens, Spirit Island can also be read as an Anthropocene Island. While the Anthropocene Working Group of the International Union of Geological Sciences may hazard that the Anthropocene began in the $20^{\text {th }}$ century (Zalasiewicz et al., 2017), characterised by the post-war Great Acceleration and nuclear age, Lewis and Maslin (2015) have alternatively argued for a 1610 start date. 1610 marks the "Colombian Exchange," the transfer of plants and animals between previously continentally separated biota, the end of a cooling period before our current ongoing period of warming, and a dip in carbon dioxide concentrations. This dip, they contend, was produced by the enormous loss of human life in the Americas and consequent reforestation and reduction in charcoal use, caused by colonial genocide and disease transmission (Lewis \& Maslin, 2015). Consequently, in proposing 1610, Lewis and Maslin highlight the colonial violence at the heart of the Anthropocene, as through the exploitation of natural resources, land, and people of and in the Americas, the emergence of industrialisation in Europe was possible. While support for such 
a starting date among geologists is minimal (Zalasiewicz et al., 2017), its proposal been commended by scholars such as Heather Davis and Zoe Todd (2017) for aligning with movements to decolonise the Anthropocene. It is also received more sympathetically by Yusoff (2018, pp. 29-33) than any of the other mainstream geological interventions, although she is critical of the depoliticised and falsely neutral language of "exchange" between Europe and the "New World." Recognition of 1610 as a start date for the Anthropocene should not, however, occlude the continental exchanges of people and material, the biological extinctions, or the damaging environmental changes that occurred prior to the $17^{\text {th }}$ century. Far earlier events, such as the extinction of mammoths through human predation (Doughty et al., 2010), the emergence of rice cultivation and corresponding forest clearances 5,000-8,000 years ago (Ruddiman, 2003), or the urban revolutions of the Bronze Age (Hann, 2017), have been used to contest the definition of the Anthropocene as a strictly modern epoch and question its efficacy as a framework overall. However, if we recognise the moment of colonial encounter as engendering the mass exploitation of people, land, and fossil fuels that produces our current epoch, then Spirit Island functions as an allegory for that moment of inception, but also presents us with a counterfactual possibility of a history that is otherwise. It demonstrates the imbrication of the human and the natural, as colonial violence is simultaneously inflicted upon people and land. If the land becomes sufficiently blighted, the whole game is lost. Moreover, if we rescale back to the metaphor of island-as-the-world, then such an analogue rings true: it is not just Spirit Island, but our whole Earth that is at risk of being irrevocably blighted. Yet, through acts of resistance and reparative justice, there is hope that such an outcome can be averted.

\section{Conclusion}

Through examining three island-themed games, I have demonstrated board games as a fertile yet underexamined field of allegorical representation, and one that is particularly pertinent to the discipline of island studies, due to the prevalence of island settings and the resonances between commonplace continental imaginaries of islands and the form and function of board games themselves. Such analysis is timely, given the newfound attention on the figure of the island across multiple scholarly fields. Chandler and Pugh (2021) contend that representations of islands as backwards, peripheral, and vulnerable are distinctly rooted in modernist frameworks of reasoning, and are being reconfigured in light of the Anthropocene's challenge to nature-culture dualisms and the ontological and onto-epistemological turn towards relational entanglements. Islands, as models of relational interdependence, no longer simply stand as metonyms for climate catastrophe, but act as central resources for both how to understand and how to respond to the Anthropocene. One can question the extent to which this shift in geographical thinking has permeated the world of board game design. However, it does indicate what is at stake in contemporary cultural island imaginaries, and suggests that representations may soon exceed the tired modernist tropes of islands as insular, bounded laboratories. Moreover, the island analytics identified by Chandler and Pugh (2021) as particularly fruitful in the Anthropocene, such as the disruption of linear modes of causality and progress, the inextricable entanglement of the human within island worlds of interconnection, and the ongoing traces and hauntings of colonialism, speak strongly to the form and content of Spirit Island and, hopefully, other games that will follow in its wake. 
Yet, can any of these figurative, cardboard Anthropocene Islands offer insights or hope with regard to the threats contemporary Pacific Island nations face from our current ecological crisis? How much of a reckoning do they present with the legacies of empire, environmental destruction, and the denial of Indigenous agency? The player-as-god of Taluva brings forth geomorphic creation and wreaks volcanic destruction, wrecking misnamed, anonymised, and unvalued island communities. The modest humanity of Vanuatu: Rising Tides seeks recourse in simple techno-fixes, divorced from locally appropriate technologies or traditional knowledges, and apolitically distanced from the causes of ecological disaster. However, Spirit Island offers us a third way: not refusing the anthropogenic nature of responsibility but also not invoking a homogenised figure of the Anthropos in seeking redress. It suggests a mode of allyship, acting collaboratively and in alliance, while showcasing the imperial exploitation of people and nature that was foundational to our new epoch. It seeks intervention, while not attempting to speak for or on behalf of those most affected. And in the polychronic time of Spirit Island, there is hope that the events of the Anthropocene can play out differently and the game can still be won.

\section{Acknowledgements}

No specific funding was received for this research. Many thanks to the two anonymous reviewers for their detailed and insightful comments, to the Anthropocene Islands special section editors Jonathan Pugh and David Chandler, and to my fellow Taluva, Vanuatu, and Spirit Island players Michael, Ava, Anna, and Mika.

\section{References}

Barnett, J., \& Campbell, J. (2010). Climate change and small island states: Power, knowledge, and the South Pacific. Earthscan. https://doi.org/10.4324/9781849774895

Beattie, S. (2020, April 29). Playing Pandemic - The hit board game about the very thing we're trying to avoid. The Conversation. https://theconversation.com/playingpandemic-the-hit-board-game-about-the-very-thing-were-trying-to-avoid-137009

Bonneuil, C., \& Fressoz, J. B. (2016). The shock of the Anthropocene: The earth, history and us. Verso.

Butler, S. (2020, April 1). Sales of board games and jigsaws soar during coronavirus lockdown. The Guardian. https://www.theguardian.com/business/2020/apr/01/sales-of-boardgames-and-jigsaws-soar-during-coronavirus-lockdown

Chambers, A. F., \& Chambers, K. S. (2007). Five takes on climate and cultural change in Tuvalu. The Contemporary Pacific, 19(1), 294-306. https://doi.org/10.1353/cp.2007.0004

Chandler, D., \& Pugh, J. (2021). Anthropocene islands: There are only islands after the end of the world. Dialogues in Human Geography. Epub ahead of print. https://doi.org/10.1177/2043820621997018

Chua, L., \& Fair, H. (2019). Anthropocene. The Cambridge Encyclopedia of Anthropology. https://doi.org/10.29164/19anthro

Crist, E. (2016). On the poverty of our nomenclature. In J. W. Moore (Ed.), Anthropocene or Capitalocene? Nature, history, and the crisis of capitalism (pp. 14-33). PM Press. 
Crutzen, P. (2002). Geology of mankind. Nature, 415, 23. https://doi.org/10.1038/415023a Davis, H., \& Todd, Z. (2017). On the importance of a date, or Decolonizing the Anthropocene. ACME: An International E-Journal for Critical Geographies, 16(4), 761780 .

DeLoughrey, E. (2019). Allegories of the Anthropocene. Duke University Press. https://doi.org/10.1215/9781478090021

Doughty, C. E., Wolf, A., \& Field, C. B. (2010). Biophysical feedbacks between the Pleistocene megafauna extinction and climate: The first human-induced global warming? Geophysical Research Letters, 37, L15703. https://doi.org/10.1029/2010GL043985

Epron, A. (2016). Vanuatu (2nd ed.) [Board game rulebook]. Quined Games.

Eskin, B. (2010, November 21). Like Monopoly in the Depression, Settlers of Catan is the board game of our time. Washington Post. https://www.washingtonpost.com/wpdyn/content/article/2010/11/24/AR2010112404140.html

Faidutti, B. (2017). Postcolonial Catan. In E. Torner, E. L. Waldron, \& A. Trammell (Eds.), Analogue game studies, volume 2 (pp. 3-34). ETC Press.

Fair, H. (2020). Their sea of islands? Pacific climate warriors, oceanic identities and world enlargement. The Contemporary Pacific, 32(2), 341-369. https://doi.org/10.1353/cp.2020.0033

Fair, H. (2019). From apathy to agency: Exploring religious responses to climate change in the Pacific Island region. In C. Kloeck \& M. Fink (Eds.), Dealing with climate change on small islands: Toward effective and sustainable adaptation (pp. 175-194). Göttingen University Press. https://doi.org/10.17875/gup2019-1216

Fair, H. (2018). Three stories of Noah: Navigating religious climate change narratives in the Pacific Island region. Geo: Geography and Environment, 5(2), e00068. https://doi.org/10.1002/geo2.68

Farbotko, C. (2010). Wishful sinking: Disappearing islands, climate refugees and cosmopolitan experimentation. Asia Pacific Viewpoint, 51(1), 47-60. https://doi.org/10.1111/j.1467-8373.2010.001413.x

Farbotko, C. (2005). Tuvalu and climate change: Constructions of environmental displacement in the Sydney Morning Herald. Geografiska Annaler, 87B(4), 279-293. https://doi.org/10.1111/j.0435-3684.2005.00199.x

Hann, C. (2017). The Anthropocene and anthropology: Micro and macro perspectives. European Journal of Social Theory, 20(1), 183-196. https://doi.org/10.1177/1368431016649362

Haraway, D. (2016). Staying with the trouble: Anthropocene, Capitalocene, Chthulucene. In J. W. Moore (Ed.), Anthropocene or Capitalocene? Nature, history, and the crisis of capitalism (pp. 34-76). PM Press.

Hau'ofa, E. (1994). Our sea of islands. The Contemporary Pacific, 6(1), 148-161.

Hereniko, V. (2014). The human face of climate change: Notes from Rotuma and Tuvalu. In W. Rollason (Ed.), Pacific futures: Projects, politics and interests (pp. 226-236). Berghahn.

Hulme, M. (2016). Weathered: Cultures of climate. SAGE. https://doi.org/10.4135/9781473957749 
Kempf, W. (2015). Representation as disaster: Mapping islands, climate change, and displacement in Oceania. Pacific Studies, 38(1-2), 200-228.

LaPensée, E. (2016). Indigenous board game design in 'The Gift of Food'. Analogue Game Studies, 3(2). http://analoggamestudies.org/2016/03/indigenous-board-game-designin-the-gift-of-food/

Lewis, S. L., \& Maslin, M. A. (2015). Defining the Anthropocene. Nature, 519(7542), 171180. https://doi.org/10.1038/nature14258

Lorimer, J. (2015). Wildlife in the Anthropocene: Conservation after nature. University of Minnesota Press. https://doi.org/10.5749/minnesota/9780816681075.001.0001

Loring-Albright, G. (2017). The First Nations of Catan: Practices in critical modification. In E. Torner, E. L. Waldron, \& A. Trammell (Eds.), Analogue game studies, volume 2 (pp. 35-42). ETC Press.

McConnell, J. R., Burke, A., Dunbar, N. W., Köhler, P., Thomas, J. L., Arienzo, M. M., Chellman, N. J., Maselli, O. J., Sigl, M., Adkins, J. F., Baggenstos, D., Burkhart, J. F., et al. (2017). Synchronous volcanic eruptions and abrupt climate change $\sim 17.7 \mathrm{ka}$ plausibly linked by stratospheric ozone depletion. Proceedings of the National Academy of Sciences, 114(38), 10035-10040. https://doi.org/10.1073/pnas.1705595114

McNamara, K. E., \& Gibson, C. (2009). We do not want to leave our land: Pacific ambassadors at the United Nations resist the category of "climate refugees". Geoforum, 40, 475-483. https://doi.org/10.1016/j.geoforum.2009.03.006

Meehan, A. (2020, March 31). Pandemic studio postpones announcement of new games in series due to real-life COVID-19 outbreak. Dicebreaker.

https://www.dicebreaker.com/series/pandemic/news/pandemic-studio-postponesseries-updates

Mosca, I. (2017). Legacy's legacy: Irreversibility and permadeath in legacy games. Analogue Game Studies, 4(1). http://analoggamestudies.org/2017/01/legacys-legacyirreversibility-and-permadeath-in-legacy-games/

Nixon, R. (2017). The Anthropocene and environmental justice. In J. Newell, L. Robin, \& K. Wehner (Eds.), Curating the future: Museums, communities and climate change (pp. 2331). Routledge.

Piggott-McKellar, A. E., Nunn, P. D., McNamara, K. E., \& Sekinini, S. T. (2020). Dam(n) seawalls: A case of climate change maladaptation in Fiji. In W. L. Filho (Ed.), Managing climate change adaptation in the Pacific region (pp. 69-84). Springer. https://doi.org/10.1007/978-3-030-40552-6 4

Pobuda, T. (2018). Assessing gender and racial representation in the board game industry. Analogue Game Studies, 5(6). http://analoggamestudies.org/2018/12/assessing-genderand-racial-representation-in-top-rated-boardgamegeek-games/

Raphel, A. (2014, February 12). The man who built Catan. The New Yorker. https://www.newyorker.com/business/currency/the-man-who-built-catan

Reuss, E. R. (2016). Spirit Island [Board game rulebook]. Fabled Nexus.

Reuss, E. R. (2015a, 22 September). Spirit Island Design Diary - Beginnings. Musings and Retrospectives:

Board Game Geek. https://www.boardgamegeek.com/blogpost/46060/spirit-island-design-diarybeginnings 
Reuss, E. R. (2015b, 16 October). Spirit Island Design Diary - Questions of setting. Musings and Retrospectives: BoardGameGeek. https://www.boardgamegeek.com/blogpost/46828/spirit-island-design-diaryquestions-setting

Robinson, W. (2016). Orientalism and abstraction in Eurogames. In E. Torner, A. Trammell, \& E. L. Waldron (Eds.), Analogue game studies, volume 1 (pp. 55-63). ETC Press.

Ruddiman, W. F. (2003). The anthropogenic greenhouse era began thousands of years ago. Climatic Change, 61, 261-293. https://doi.org/10.1023/B:CLIM.0000004577.17928.fa

Schelle, C. (2020, March 31). Pandemic board game sells out as coronavirus sweeps across Australia. 7News.com.au. https://7news.com.au/lifestyle/health-wellbeing/pandemicboard-game-sells-out-as-coronavirus-sweeps-across-australia-c-901114

Steiner, C. E. (2015). A sea of warriors: Performing an identity of resilience and empowerment in the face of climate change in the Pacific. The Contemporary Pacific, 27(1), 147-180. https://doi.org/10.1353/cp.2015.0002

Stenros, J. (2014). In defence of a magic circle: The social, mental and cultural boundaries of play. Transactions of the Digital Games Research Association, 1(2), 147-185. https://doi.org/10.26503/todigra.v1i2.10

Swindles, G. T., Watson, E. J., Savov, I. P., Lawson, I. T., Schmidt, A., Hooper, A., Cooper, C. L., Connor, C. B., Gloor, M., \& Carrivick, J. L. (2018). Climatic control on Icelandic volcanic activity during the mid-Holocene. Geology, 46(1), 47-50. https://doi.org/10.1130/G39633.1

Swyngedouw, E. (2010). Apocalypse forever? Post-political populism and the spectre of climate change. Theory, Culture \& Society, 27(2-3), 213-232. https://doi.org/10.1177/0263276409358728

Teaiwa, K. M. (2014). Re-framing Oceania: Lessons from Pacific studies. In H. Kahn (Ed.), Framing the global: Entry points for research (pp. 67-96). Indiana University Press.

Technavio. (2020). Board games market by product, distribution channel, and geography - Forecast and analysis 2020-2024. https://www.technavio.com/report/board-games-marketindustry-analysis

Todd, Z. (2016). An indigenous feminist's take on the ontological turn: 'Ontology' is just another word for colonialism. Journal of Historical Sociology, 29(1), 4-22. https://doi.org/10.1111/johs.12124

Torner, E., Trammell, A., \& Waldron, E. L. (2016). Reinventing analog game studies: Introductory manifesto. In E. Torner, A. Trammell, \& E. L. Waldron (Eds.), Analogue game studies, volume 1 (pp. 1-5). ETC Press.

Tsing, A. L., Swanson, H. A., Gan, E., \& Bubandt, N. (Eds.). (2017). Arts of living on a damaged planet: Ghosts and monsters of the Anthropocene. University of Minnesota Press.

Whyte, K. P. (2018). Indigenous science (fiction) for the Anthropocene: Ancestral dystopias and fantasies of climate change crises. Environment and Planning E: Nature and Space, 1(12), 224-242. https://doi.org/10.1177/2514848618777621

Wired (2009, 23 March). Monopoly killer: Perfect German board game redefines genre. Wired. https://www.wired.com/2009/03/mf-settlers/ 
Yusoff, K. (2018). A billion Black Anthropocenes or none. University of Minnesota Press. https://doi.org/10.5749/9781452962054

Zalasiewicz, J., Waters, C. N., Summerhayes, C. P., Wolfe, A. P. Barnosky, A. D., Cearreta, A., Crutzen, P., Ellis, E., Fairchild, I. J., Gałuszka, A., Haff, P., Hajdas, I., et al. (2017). The working group on the Anthropocene: Summary of evidence and interim recommendations. Anthropocene, 19, $55-60$. https://doi.org/10.1016/j.ancene.2017.09.001 